\title{
AutOagresYWNy WZORZEC ADAPTACJI A CZYNNIKI OSOBOWOŚCI HEXACO
}

\author{
Antonina Panek \\ Instytut Psychologii \\ Uniwersytet Wrocławski \\ ul. J. Wł. Dawida 1, 50-527 Wrocław \\ e-mail: 289311@uwr.edu.pl \\ ORCID: https://orcid.org/0000-0002-9903-6796 \\ Barbara Żyżelewicz \\ Instytut Psychologii \\ Uniwersytet Wrocławski \\ ul. J. Wł. Dawida 1, 50-527 Wrocław \\ e-mail: 299418@uwr.edu.pl \\ ORCID: https://orcid.org/0000-0002-4858-1647 \\ Arletta Franczak \\ Instytut Psychologii \\ Uniwersytet Wrocławski \\ ul. J. Wł. Dawida 1, 50-527 Wrocław \\ e-mail: arlettafranczak@gmail.com \\ ORCID: https://orcid.org/0000-0003-0201-3465 \\ Anna Krajniak \\ Instytut Psychologii \\ Uniwersytet Wrocławski, \\ ul. J. Wł. Dawida 1, 50-527 Wrocław \\ e-mail: an.krajniak@gmail.com \\ ORCID: : https://orcid.org/0000-0002-8651-0874
}

\section{Abstrakt}

Cel. Celem artykułu jest przedstawienie związku między autoagresywnym wzorcem adaptacji a czynnikami osobowości HEXACO. Autoagresywny wzorzec adaptacji to nabyty sposób reagowania na otaczające jednostkę środowisko. Charakteryzuje się reakcjami agresywnymi skierowanymi wobec własnej osoby. Jest powiązany z antyspołecznym zaburzeniem osobowości oraz zaburzeniem borderline.

Metody Badań. Do przeprowadzenia badań wykorzystano Kwestionariusz Osobowości HEXACO-60 (Ashton, Lee, 2007) oraz Kwestionariusz JakalJaki Jesteś? (Łoś, 2013). Przebadano 330 osób w wieku 18-40 lat. 
Wyniki. Wykazano, że autoagresywny wzorzec adaptacji istotnie statystycznie koreluje z takimi czynnikami osobowości jak: uczciwość, ekstrawersja, ugodowość i sumienność (wszystkie negatywnie) oraz emocjonalność (pozytywnie). Nie stwierdzono istotnych związków z otwartością.

Wnioski. Autoagresywny wzorzec adaptacji charakteryzuje się układem czynników, który może powodować gorsze przystosowanie społeczne jednostki. Uzyskane wyniki mogą zostać wykorzystane w praktyce klinicznej, wychowawczej i socjalnej, poprawiając jakość życia osób o takiej charakterystyce oraz zwiększając szanse na wczesne wykrycie ewentualnych zaburzeń u adolescentów. Ograniczeniem metody była mała ilość osób badanych w wieku dojrzewania, ze względu na utrudniony dostęp do tej grupy wiekowej (ograniczenia prawne wynikające z niepełnoletności respondentów, mniejsza ilość połączeń społecznych z tą grupą wiekową).

Słowa kluczowe: autoagresywny wzorzec adaptacji, osobowość, HEXACO, antyspołeczne zaburzenie osobowości, zaburzenie borderline.

The auto-aggressive pattern of adaptation and its connection with the HEXACO personality factors

\section{Abstract}

Aim of the study. The aim of this article is to present the relationship between the auto-aggressive pattern of adaptation and HEXACO personality factors. An auto-aggressive adaptation pattern is an acquired way of responding to the surrounding environment. It is characterized by self-directed aggressive reactions. It is associated with anti-social personality disorder and borderline personality disorder.

Research method. The participants completed the HEXACO-60 Personality Inventory (Lee, Ashton, 2007) and Questionnaire Jaka/Jaki Jesteś? (What Are You Like?) (Łoś, 2013). The study involved 330 people between the ages of 18 and 40.

Results. It has been shown that the auto-aggressive pattern of adaptation statistically significantly correlates with such personality factors as Honesty-Humility, Extraversion, Agreeableness and Conscientiousness (all adversely), and Emotionality (favourably). No significant relationship with Openness to Experience was found.

Conclusion. An auto-aggressive pattern of adaptation is characterized by a system of factors which can cause an individual to become less socially adapted. The results obtained here can be used in clinical, educational and social practice, improving the quality of life of people with such characteristics and increasing the chances of early detection of possible disorders in adolescents. The method was limited by the significantly reduced number of adolescent participants (legal restrictions resulting from the respondents' underage status, or fewer social connections with this age group).

Key words: autoaggressive pattern of adaptation, personality, HEXACO, anti-social personality disorder, borderline disorder.

\section{Problem PRZYSTOSOWANIA I OSOBOWOŚć}

W dynamicznie rozwijającym się świecie zewnętrznym przystosowanie jednostki do panujących warunków jest niezbędne do zachowania pełni sił fizycznych i psychicznych. Obserwując najbliższe otoczenie społeczne, można doszukać się różnic 
w funkcjonowaniu poszczególnych osób. Jednym z niepokojących i kosztownych społecznie zjawisk są zachowania autoagresywne obserwowane wśród adolescentów i osób dorosłych (Sharaf, Thompson, Walsh, 2009). W jaki sposób wiążą się one z uwarunkowaniami osobowościowymi? Czy na podstawie badania kwestionariuszem osobowości niezawierającym pytań o bardzo prywatne zachowania można rozpoznawać tendencje autoagresywne $\mathrm{u}$ adolescentów i dorosłych? Celem tej pracy jest znalezienie empirycznych odpowiedzi na postawione pytania.

Osobowość człowieka rozumiana jest jako szerokie pojęcie dotyczące właściwości jednostki takich jak: zachowania i specyficznego sposobu reagowania na świat (Pervin, John, 2002). Ten „system" uwarunkowany biologicznie i społecznie odpowiada za przeżycia wewnętrzne jednostki oraz jej funkcjonowanie w społeczeństwie. Pojęciem osobowości w badaniach naukowych i literaturze akademickiej najczęściej operuje się w kontekście teorii cech (Grabski, Gierowski, 2012). Przyglądając się uważnie historycznym przemianom, wśród teorii cech wyróżniano dwa podstawowe modele definiujące wymiary osobowości: Wielką Piątkę (zawierającą pięć wymiarów osobowości) oraz Gigantyczną Trójkę Eysencka (trzy wymiary osobowości) (Costa, McCrae, 1992; Eysenck, 1992). Teorie te zakładają różną ilość wymiarów wyczerpująco definiujących jednostkę, a główną oś sporu między badaczami stanowi poszukiwanie optymalnej liczby cech (Strus, Cieciuch, 2014.

Jedną z alternatywnych teorii jest sześcioczynnikowy model HEXACO rozszerzający Wielką Piątkę o dodatkowy wymiar Uczciwość (Hon) i redefiniujący pozostałe czynniki (Ashton i Lee, 2007). Model ten jest nazywany hierarchicznym, gdyż w skład głównych czynników wchodzą jego bardziej szczegółowe aspekty, różniące się od Wielkiej Piątki (Strus, Cieciuch, 2011). Autorzy HEXACO w swojej publikacji (Ashton, Lee, 2007) argumentuja że model sześcioczynnikowy w aspekcie teoretycznym trafniej wyjaśnia zjawiska społeczne i ewolucyjne niż proponowane wcześniej modele, dlatego posłużono się nim w tym badaniu.

\section{ZACHOWANIA AUTOAGRESYWNE}

Zachowania autoagresywne to spektrum czynności od bezpośrednio mających na celu samookaleczenie jednostki podejmującej je, przez czynności pośrednio narażające na doznanie krzywdy, czyli na przykład prowokowanie sytuacji, w których można stać się ofiarą agresji innych (Roszkowska, 2018). Pośrednio okaleczać można się nie tylko fizycznie, ale również werbalnie, formułując obciążające i krytyczne oskarżenia pod swoim własnym adresem w samotności lub w towarzystwie innych osób. Aaron Beck i współpracownicy (1979) zwrócili uwagę, że tendencje autodestrukcyjne mogą wyrażać się $\mathrm{w}$ czternastu deformacjach procesów poznawczych, takich jak np. nadmierne uogólnienia, czy wyciąganie arbitralnych i negatywnych wniosków (Pilecka, 2004 za: Beck i in. 1979).

Jednostki podejmują działania autoagresywne m.in. w celu doznania ulgi od napięcia spowodowanego emocjami, które stają się nie do zniesienia lub poczuciem derealizacji czy apatią (Linowski, Wysocki, 2012). Przejawem autoagresji nie muszą być jednak tylko zachowania, może to być także powstrzymanie się od adaptacyjnych zachowań. Anna Suchańska (1998), analizując autodestruktywność pośrednia, wymieniła: zaniedbania zdrowotne, zaniedbania osobiste i społeczne, nieuważność i nieostroż-

Ogrody Nauk i Sztuk nR 2021 (11) 
ność, oraz pasywność wobec trudności i niepowodzeń. Jednakże konstruując narzędzie empiryczne, stwierdziła, że odpowiednie twierdzenia kwestionariusza nie tworzą „wyraźnych skupień” (Suchańska, 1998, s. 161), co sugeruje, że wystarczy ujęcie zagadnienia jako jednowymiarowego.

Bessel van der Kolk wraz z Christopherem Perrym i Judith Herman (1991) odnaleźli zależności pomiędzy traumatycznymi doświadczeniami na tle seksualnym, różnego rodzaju przemocą fizyczną, emocjonalną i innego rodzaju nadużyciami fizycznymi, a zachowaniami autoagresywnymi. Również niekonsekwentny styl wychowania i elementy konstrukcji psychicznej, takie jak niska samoocena czy nasilony perfekcjonizm, mogą przyczyniać się do wykształcenia autodestrukcyjnych metod radzenia sobie=

Ponadto zachowania autoagresywne są jednym z symptomów zaburzenia osobowości typu borderline. (WHO, 1998; Wojda, 2018). Organizacja psychiczna to dynamiczna całość, która może ulec destabilizacji. Zaburzenia kliniczne zawsze wskazują na nieprawidłowe, odbiegające od przyjętej normy zachowania, jednak niekoniecznie trwałe. Zaburzenia osobowości to trwały sposób funkcjonowania jednostki, ale o charakterze subklinicznym. Wzorzec adaptacji zajmuje miejsce między prawidłowym przystosowaniem a zaburzeniem osobowości lub klinicznym. Wielu autorów (Mosak, 1971; Oldham, Morris, 1995; Łoś, 2010) wyróżnia kilkanaście stylów życia, osobowości lub wzorców adaptacji, które nawiązują do klasyfikacji psychiatrycznych, jednak niezbyt ściśle. Wzorzec adaptacji powstaje $\mathrm{w}$ wyniku konsolidowania doświadczeń ze środowiska, w którym osoba o względnie stałych cechach temperamentalnych i osobowościowych funkcjonowała (rodzina i środowisko pozadomowe). Klasyfikacja wzorców adaptacji została stworzona ze względu na cele i środki aktywności jednostki składające się na powtarzalną strategię funkcjonowania podmiotu. Poszczególne wzorce uwzględniają rodzaj wpływu innych ludzi wywierany na dziecko, wyrażający się w komunikacie, hipotetyczną odpowiedź na wpływ socjalizacyjny w dzieciństwie oraz chroniczny cel aktywności w dorosłości (Łoś, 2010).

Szczególnie interesujący wydaje się wzorzec Autoagresywny. W dzieciństwie osoba o takim wzorcu adaptacji odczuwała ze strony otoczenie karę jako permanentną potrzebę zadowalania innych. Implikacją jest hipotetyczna odpowiedź dziecka - "jestem do usług", co ukształtowało "niszczenie zła" w sobie jako chroniczny cel aktywność podmiotu w życiu dorosłym. Dodatkowo warte obserwacji wzorce koncentrujące się wokół wyrażania agresji to: bierno-agresywny i kontrolująco-agresywny

\section{Cel badań}

Celem badania było sprawdzenie, czy istnieje związek między autoagresywnym wzorcem adaptacji a czynnikami osobowości HEXACO. Biorąc pod uwagę założenia teoretyczne i wyniki badań, postawiono następujące pytanie: Czy autoagresywny wzorzec adaptacji wykazuje z czynnikami osobowości (Emocjonalnościa, Uczciwością-Pokora, Sumiennością, Otwartościa, Ekstrawersją, Ugodowością)?

Na podstawie przesłanek teoretycznych dotyczących neurotyczności w modelu Wielkiej Piątki i w badaniach Eysencka postawiono hipotezę, że Autoagresywny wzorzec adaptacji koreluje pozytywnie z Emocjonalnością, a negatywnie z pozostałymi czynnikami osobowości (Eysenck, 1992). 


\section{Metoda}

W badaniach zastosowano metodę kwestionariuszową z wykorzystaniem podanych narzędzi:

Inwentarz Osobowości HEXACO-60 - jest to kwestionariusz autorstwa Kibeom Lee i Michaela C. Ashtona (Ashton, Lee, Szarota 2004) składa się z sześciu podstawowych wymiarów osobowości w modelu HEXACO to: Honesty-Humility (Uczciwość-Pokora), Emotionality (Emocjonalność), Extraversion (Ekstrawersja), Agreeablenes (Ugodowość), Consiensnousness (Sumienność) i Opennes to expierience (Otwartość). Zawiera 60 itemów określających czynniki osobowości. Każda z sześciu skal liczy po dziesięć itemów, format odpowiedzi jest pięciopunktowy (5 = zdecydowanie się zgadzam, 4 = zgadzam się, 3 = ani tak, ani nie, 2 = nie zgadzam się, 1 = zdecydowanie się nie zgadzam). Skale składają się z czterech podskal dwu- lub trzyitemowych i niewysokiej rzetelności, która była powodem niewyodrębnienia owych składowych w analizie. Natomiast przedstawiona interpretacja wyników zawiera odwołania do specyfiki podskal w celu przybliżenia psychologicznej istoty czynników HEXACO.

Kwestionariusz Jaka/Jaki Jesteśs (JJJ, Łoś, 2013) - narzędzie to służy do pomiaru 15 wzorców adaptacji. Składa się z ośmioitemowych skal utworzonych w formie pytającej, np.: „Czy jesteś człowiekiem uczuciowym, ale jednocześnie szybko zmieniają ci się nastroje?". Występuje tu czteropunktowy format odpowiedzi: tak, raczej tak, raczej nie, nie. Rzetelność skal mieści się w przedziale 0,62-0,83 (Łoś, 2013). Skale kwestionariusza mają charakter jednobiegunowy - większość itemów w określonej skali opisuje wysokie natężenie mierzonej zmiennej. Z narzędzia wybrałyśmy trzy wzorce adaptacji: auto-agresywny, bierno-agresywny oraz kontrolująco-agresywny. Alfa Cronbacha z badań własnych było równe 0,9 .

Przykładowe itemy JJJ:

Augr (Autoagresywny wzorzec adaptacji):

"48. Czy zdarza Ci się zadawać sobie ból?"

“82. Czy zdarza Ci się czuć nienawiść do samej/samego siebie?”

"110. Czy odczuwasz czasem chęć zrobienia sobie czegoś złego?”

Biagr (Bierno-agresywny wzorzec adaptacji):

“25. Czy uważasz, że wielu ludziom powiodło się niezasłużenie?”

"86. Czy uważasz, że większość ludzi nie zasługuje na poważne traktowanie?"

Koagr (Kontrolująco-agresywny wzorzec adaptacji):

“23. Czy należysz do ludzi, którzy zaczepki nie zostawiają bez odpowiedzi?”

“54. Czy potrafisz ośmieszyć kogoś, kto działa Ci na nerwy?”

\section{CharakTerystyka I DOBóR PRóby}

W badaniu wzięło udział $N=330$ osób w wieku od 18 do 40 lat. Spośród tych osób $50 \%$ stanowiły kobiety). Średnia wieku osób badanych wynosiła $M=27$ lat. Uczestnicy zostali poinformowani o celu badania, dobrowolności uczestnictwa i poufności oraz wykorzystaniu wyników wyłącznie do celów naukowych. Badani pojedynczo wypełniali wyselekcjonowany zestaw kwestionariuszy. Przedstawione wyniki stanowią element większego badania, którego omówienie przekraczałoby ramy tego artykułu. Badanie zostało wykonane w lutym i marcu 2020 roku.

Ogrody Nauk i SzTuk nR 2021 (11) 


\section{Analiza wyniKów}

Na początku analizy dokonano charakterystyki opisowej zmiennych oraz korelacje Pearsona pomiędzy wybranymi zmiennymi. Zawiera je tabela 1.

Tabela 1. Statystyki opisowe badanych zmiennych $(N=330)$

\begin{tabular}{lcc}
\hline Zmienna & $M$ & $S D$ \\
\hline Otwartość & 33.06 & 6.95 \\
Sumienność & 34.89 & 6.43 \\
Ugodowość & 30.72 & 5.86 \\
Ekstrawersja & 31.80 & 6.05 \\
Emocjonalność & 30.39 & 6.98 \\
Uczciwość-Pokora & 31.91 & 6.95 \\
Wzorzec autoagresywny & 7.78 & 5.11 \\
Wzorzec bierno-agresywny & 11.61 & 4.15 \\
Wzorzec kontrolująco-agresywny & 11.74 & 4.19 \\
\hline
\end{tabular}

Adnotacja: $M$ - Średnia; SD - Odchylenie standardowe.

Żródto: Badania własne.

Tabela 2. Korelacje Pearsona pomiędzy wybranymi zmiennymi $(N=330)$

\begin{tabular}{lccc}
\hline Zmienna & $\begin{array}{c}\text { Kontrolująco- } \\
\text { agresywny }\end{array}$ & Bierno-agresywny & Auto-agresywny \\
\hline Uczciwość & -.38 & -.47 & -.32 \\
Emocjonalność & -.25 & -.05 & .27 \\
Ekstrawersja & .42 & -.11 & -.41 \\
Sumienność & -.06 & -.17 & -.3 \\
Ugodowość & -.31 & -.41 & -.27 \\
Otwartość & .16 & -.01 & .03 \\
\hline
\end{tabular}

Adnotacja: Wytłuszczone efekty istotne statystycznie. $\mathrm{p}<0,05$.

Żródło: Badania własne.

Ze względu na duże różnice $\mathrm{w}$ sytuacji życiowej badanych podzielono na młodszych (18-26 lat, $N=166$ ) i starszych (27-40 lat, $N=164)$. Znaczenie różnic związanych $\mathrm{z}$ wiekiem sprawdzono $\mathrm{w}$ analizach uwzględniając równoliczny podział na młodszych i starszych, jednak te efekty, które mogłyby być interesujące interpretacyjnie nie osiągnęły istotności statystycznej, mimo licznej próby osób badanych. W związku z tym $\mathrm{w}$ dalszej części artykułu zagadnienie to nie zostaje ponownie poruszone.

Porównano także kobiety i mężczyzn pod względem zmiennych kwestionariuszowych. Znaleziono istotne różnice w czynnikach Uczciwość (Hon), Emocjonalność (Emo), a w skali Autoagresywność (Auagr) nie wykazano takiej różnicy. Przystępując do dalszych analiz, usunięto różnice związane z płcią za pomocą standaryzacji danych surowych osobno dla każdej płci (tak jak w przypadku stosowania osobnych norm w kwestionariuszach osobowości i temperamentu). Taki zabieg nie zmniejsza prawdopodobieństwa, że związki między zmiennymi mogłyby być inne dla kobiet oraz mężczyzn. 
Wykorzystując program Statistica, sprawdzono, jakie zależności można zaobserwować pomiędzy wybranymi cechami osobowości a wzorcami adaptacji kontrolująco-agresywnymi, bierno-agresywnymi i auto-agresywnymi (zawarte w tabeli 2).

Analizując wyniki w tabeli 2 widać, że wzorzec auto-agresywny koreluje aż z pięcioma czynnikami osobowości HEXACO (uczciwość, emocjonalność, ekstrawersja, sumienność i ugodowość), natomiast nie wykazuje istotnych korelacji z otwartością. Mogłoby to świadczyć o wysoce niespecyficznym zakresie pomiaru wzorca autoagresywnego, jednak warto zwrócić uwagę na to, że czynniki HEXACO mają dość podobny układ korelacji ze wzorcem bierno-agresywnym, ale jednocześnie bardziej odmienny od wzorca kontrolująco-agresywnego (który z założenia jest wzorcem bardziej aktywnym niż dwa pozostałe). Zróżnicowanie wspomnianych korelacji może być pośrednim argumentem na rzecz trafności różnicowej skali auto-agresywnej.

Tym co w powyższej tabeli jest zaskakujące, to ujemne korelacje wzorca Autoagresywnego z Uczciwością $(r=-0,32, p<0,05)$, Ugodowością $(r=-0,27, p<0,05)$ i Sumiennością $(r=-0,30, p<0,05)$. Układ wymienionych korelacji oznacza, że osoby autoagresywne są negatywnie nastawione do norm społecznych $\mathrm{i}$ innych ludzi, a nie ugodowe i podporządkowane.

Ponieważ wzorzec Autoagresywny ma istotne związki z pięcioma czynnikami HEXACO, które wykazują korelacje między sobą (tabela 2), powstało pytanie, ile procent zmienności mogą wyjaśnić. Wykonana analiza regresji wykazała, że ponad 30\% (skorygowane $R^{2}=0,334$ ). Jest to wysoki wynik zważywszy, że między treścią skal HEXACO-60 a skalą Auagr nie ma dużych podobieństw treściowych. Poszczególne współczynniki regresji mają znak taki jak odpowiadające im korelacje. Dodatkowo istotny udział ma czynnik Otwartości, którego korelacja z Autoagresywnością była bliska zeru. Sugeruje to, że osobowościowe uwarunkowania tendencji autogresywnych są zaskakująco skomplikowane.

Z punktu widzenia zastosowań tych wyników w praktyce terapeutycznej czy pedagogicznej, korzystniejsze byłoby przedstawienie konstrukcji psychicznej osób autoagresywnych w postaci profilu osobowości, co mogłoby posłużyć jako inspiracja do przyszłych badań.

Analizując wyniki tabeli 2, widać dodatkowo, że bierno-agresywny wzorzec adaptacji istotnie statystycznie koreluje z uczciwością $(r=-0,47, p<0,05)$. Jest to korelacja ujemna, czyli im osoba jest bardziej uczciwa, tym rzadziej stosuje wspomniany wzorzec adaptacji. Znaczącą korelację wykazano również między Ekstrawersją, a wzorcem kontrolująco-agresywnym $(r=0,42, p<0,05)$. Dodatnia jej wartość świadczy o tym, że osoby o cechach ekstrawertycznych często stosują kontrolująco-agresywny wzorzec adaptacji.

Zaskakujące jest również to, że wszystkie wybrane wzorce korelują ujemnie z uczciwością oraz ugodowością. Może mieć to związek ze słabym uspołecznieniem osób przejawiających cechy agresywne.

\section{ANAliza PROFILOWA}

Kolejnym krokiem analizy było wyodrębnienie osób, o których można by zasadnie stwierdzić, że charakteryzują się podwyższonymi tendencjami autoagresywnymi. W skali stenowej byłyby to wyniki od 7 stena wzwyż, jednak do kwestionariusza JJJ

Ogrody Nauk i Sztuk nR 2021 (11) 
nie ma aktualnie norm stenowych. Wobec tego odszukano około jednej trzeciej osób o najwyższych wynikach w skali Auagr. Ze względu na identyczne wyniki kilku osób w miejscu, gdzie wypadałoby rozgraniczenie, jest to nieco mniej niż $33 \%$ badanych (47 kobiet i 47 mężczyzn), przy czym po połowie z grupy „młodszych" i „starszych" badanych. Pozostali badani (236 osób) stanowią grupę porównawczą. Standaryzowane wyniki HEXACO dla kobiet i mężczyzn o podwyższonych wynikach w skali Autoagresywnego wzorca adaptacji na tle pozostałych badanych przedstawia Rysunek 1.

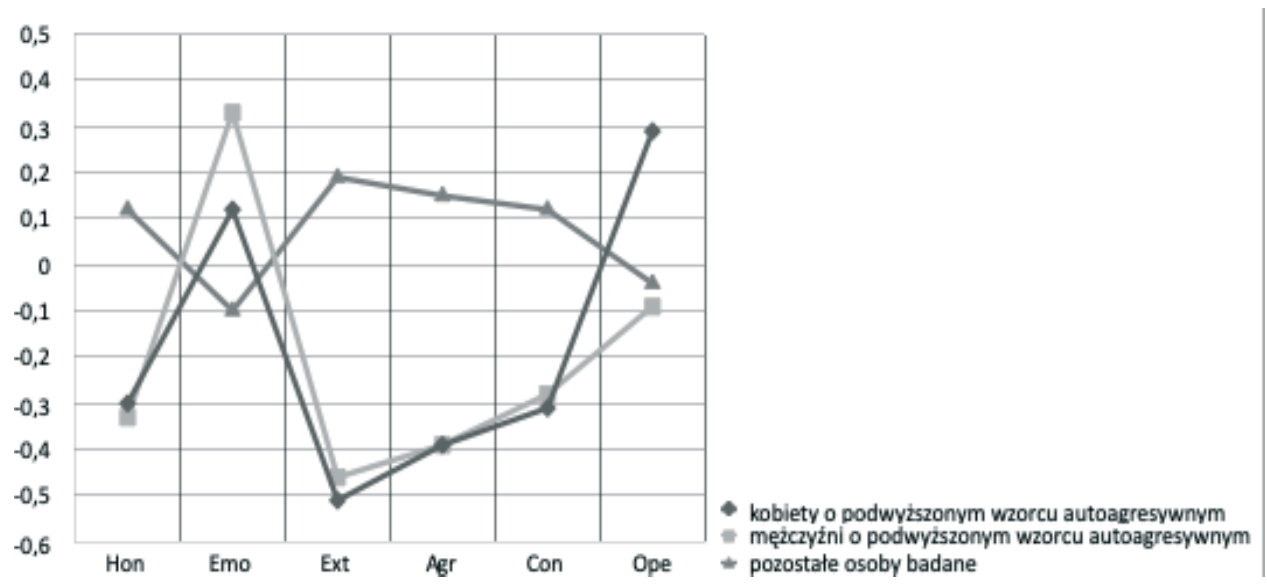

Rysunek 1. Różnice w nasileniu czynników osobowości między kobietami a mężczyznami o podwyższonym Autoagresywnym wzorcu adaptacji.

Adnotacja: Hon - Uczciwość, Emo - Emocjonalność, Ext - Ekstrawersja, Agr - Ugodowość, Con - Sumienność, Ope - Otwartość.

Źródło: Badania własne

Ze względu na niekorzystne wyniki testu jednorodności wariancji istotność różnic między grupami była oceniana testami nieparametrycznymi (Kruskala-Wallisa, z opcją wielokrotnych porównań średnich rang - program Statistica 13).

Wytypowane kobiety mają istotnie niższą Uczciwość, Ekstrawersję i Ugodowość (a Sumienność na poziomie tendencji, $p<0,07)$. Emocjonalność i Otwartość wytypowanych kobiet nie odbiega istotnie od wyników pozostałych badanych.

Wytypowani mężczyźni mają istotnie niższą Uczciwość, wyższą Emocjonalność, niższą Ekstrawersję, Ugodowość i Sumienność niż grupa „pozostałych” badanych.

Profil kobiet i mężczyzn o podwyższonym Autoagresywnym wzorcu adaptacji jest zatem wysoce analogiczny. Jedni i drudzy są introwertywni oraz słabo uspołecznieni (wskazują na to obniżone wyniki w skalach Uczciwość, Ugodowość i Sumienność), a mężczyźni dodatkowo emocjonalni. Istotność różnic była testowana testem dla rang, lecz rysunek przedstawia średnie wyników standaryzowanych, dzięki czemu łatwiej ocenić wielkość tych odchyleń. Zważywszy, że mowa o uśrednionych wynikach grupowych, należy zwrócić uwagę na to, że obniżenia (od 0,3 do 0,5 odchylenia standardowego w dół od średnich dla ogółu 330 badanych (czyli 0,00) są znaczne i stanowią dobry powód do zwiększenia zainteresowania badaczy tą problematyką 
(zwłaszcza że społeczne skutki izolacji spowodowanej pandemią mogą zwiększyć rozpowszechnienie adaptacji autoagresywnej (również bierno-agresywnej oraz kontrolująco-agresywnej).

\section{DYSKUSJA I WNIOSKI}

W powyższej pracy wykazano istotne związki między autoagresywnym wzorcem adaptacji a czynnikami osobowości. Analiza wyników wskazała na to, że osoby charakteryzujące się badanym wzorcem mają obniżony poziom Ekstrawersji, Uczciwości, Ugodowości i Sumienności oraz charakteryzują się podwyższoną Emocjonalnością. W potocznym rozumieniu osoba autoagresywna jest postrzegana jako zamknięta w sobie i nienawiązująca kontaktów z otoczeniem. Dorota Kubacka-Jasiecka (2006), definiuje zachowania autoagresywne jako dobrowolne pośrednio lub bezpośrednio zagrażające zdrowiu społecznemu, emocjonalnemu i fizycznemu jednostki. Do zachowań autoagresywnych pośrednich, które rzadko przykuwają uwagę badaczy, a są istotne należą na przykład: rezygnacja z niektórych aktywności, samoutrudnianie, dążenie do porażki, nałogi oraz zaniedbanie zdrowotne (Tsirigotis, Gruszczyński, Lewik-Tsirigotis, Kruszyna, 2011). Głównym powodem autoagresji jest regulacja poziomu napięcia odczuwanego przez jednostkę Przyczyną może być także radzenie sobie z cierpieniem i nadmiarem emocji (Roszkowska, 2018).

Analizując pozytywny związek autoagresywnego wzorca adaptacji z Emocjonalnością (u mężczyzn), można stwierdzić, że osoba charakteryzująca się: lękowościa, strachliwościa, sentymentalnością oraz zależnością (Lee, Ashton, 2004) ma cechy adaptacji autoagresywnej. Taka osoba może wykazywać problemy z podjęciem nowych wyzwań, a także zbytnim przywiązaniem do przeszłości w kontekście relacji i przedmiotów materialnych (hexaco.org). Informacje te mogą być wykorzystane w procesie diagnostyki zaburzeń osobowości dotykających osób o wysokiej wrażliwości emocjonalnej. Charakterystycznym zaburzeniem, które na poziomie behawioralnym cechuje nieoczekiwana reakcja emocjonalna, jest zaburzenie osobowości borderline. $\mathrm{W}$ obrazie klinicznym tego zaburzenia wyróżnia się nagłe reakcje w postaci autoagresji w sytuacjach trudnych (Cierpiałkowska, 2017). Pokrewne badania nad osobowością borderline wskazują na jej związek z neurotycznością (Distel i in., 2009), a wyniki są wyższe $(r=0.68)$ niż w prezentowanym badaniu $(r=0,27)$.

Czynnik sumienność HEXACO w przeprowadzonym badaniu wykazuje negatywny związek z autoagresywnym wzorcem adaptacji. Podobne wyniki uzyskano w badaniach nad autoagresywnymi zachowaniami, które nie kończyły się samobójstwem (NSSI - Nonsuicidal Self-Injury) u dorastających kobiet, gdzie osoby, które obserwowano cechowały się obniżoną sumiennością (Perlman, Gromatsky, Salis, Klein, Kotov, 2018).

W badaniu uzyskano negatywną korelację czynnika ekstrawersja z autoagresywnym wzorcem adaptacji. W publikacjach opartych na Wielkiej Piątce (w odniesieniu do zaburzeń osobowości) uzyskano wyniki zarówno zbieżne z prezentowanym badaniem (Bagby, Costa, Widiger, Ryder Marshall, 2005), jak również te niejednoznaczne, gdzie przykładowo dla psychopatii i skłonności do agresji wyniki oscylowały między niskimi oraz wysokimi (Jones, Miller, Lynam, 2011). Istnieje więc możliwość, że osoby autoagresywne moga, ale nie muszą charakteryzować się niską ekstrawersją.

Ogrody Nauk i Sztuk nR 2021 (11) 
Czynnikiem, który nie korelował w powyższym badaniu z analizowanym wzorcem była otwartość, rozumiana jako pewien rodzaj wrażliwości na piękno i sztukę oraz swobodę w używaniu wyobraźni w codziennym życiu (Ashton, Lee, 2007) Powołując się na badania przeprowadzone nad osobowością borderline, podobnie nie wykazano istotnych statystycznie zależności (DeShong, Mullins-Sweatt, Miller, Widiger, Lynam, 2016).

Autoagresywny wzorzec adaptacji wykazuje negatywny związek z czynnikiem Ugodowość. W literaturze także wskazuje się na negatywną korelację zaburzenia osobowości borderline z ugodowością modelu Wielkiej Piątki (Trull, Widiger, Lynam, Costa, 2005). Osoby o takim wzorcu charakteryzuje krytyczne osądzanie innych i niechęć współpracy.

Negatywny związek z autoagresywnym wzorcem adaptacji wykazuje także Uczciwość. Osoby uzyskujące niskie wyniki na tej skali cechuje motywowanie przez zysk materialny (zainteresowanie luksusem) oraz silna potrzeba poczucia własnej ważności i podwyższania statusu społecznego, a to dla osób przykładowo uwikłanych w zakupoholizm może wydawać się istotne.

$\mathrm{W}$ fazie obliczeń sprawdzono, czy zachodzą istotne różnice $\mathrm{w}$ uzyskanych wynikach między kobietami i mężczyznami. W czynnikach takich jak uczciwość, emocjonalność oraz autoagresywność uzyskano różnice, jednak w dalszych analizach wystandaryzowano dane analogicznie jak w przypadku kwestionariuszy osobowości i temperamentu. Uzyskane wyniki pokazuja że osoby o podwyższonym autoagresywnym wzorcu adaptacji mają podobny profil osobowości niezależnie od płci (różnice tylko w poziomie Emocjonalności).

Uzyskane wyniki pozwalają na dokładniejsze zrozumienie zależności między wzorcami adaptacji a cechami osobowości. Mogą one posłużyć w praktyce klinicznej, wychowawczej i socjalnej, poprawiając tym samym jakość życia osób charakteryzujących się tym wzorcem. Profil z obniżonymi czynnikami uspołecznienia jest ważną wskazówką dla sposobu postępowania specjalistów z osobami autoagresywnymi. Wydaje się również, że dzięki wczesnemu zaobserwowaniu autoagresywnego wzorca adaptacji będzie można sprawniej prowadzić diagnostykę pod kątem zaburzeń osobowości. Kluczowe może być również rozpoznanie zachowań autoagresywnych u adolescentów, którzy niechętnie otwierają się przed wychowawcami i środowiskiem.

Przeprowadzone badanie kwestionariuszowe wiązało się z wieloma ograniczeniami. Głównym z nich była czasochłonna metoda stacjonarna (papierowe arkusze badawcze), która znacznie zmniejszyła liczbę potencjalnych badanych. W przyszłości warto zastanowić się nad internetową wersją powyższego badania, aby bardziej różnicować osoby zainteresowane pod względem wieku i miejsca zamieszkania. Wydaje się również, że badanie z wykorzystaniem najnowszych metod informatycznych zachęci do udziału osoby młodsze, co pozwoli na większe zróżnicowanie wyników ze względu na wiek.

Ponieważ wyniki uzyskano przed kryzysową sytuacją światowa jaką była pandemia, istnieje duże prawdopodobieństwo uzyskania innych (najprawdopodobniej podwyższonych) wartości w przypadku ponownego badania po przymusowej zmianie funkcjonowania społeczeństwa. Wymuszona alienacja utrudniała kontakty międzyludzkie i zwalniała z konieczności angażowania się w interakcje, które wcześniej 
były konieczne w życiu codziennym, tym samym pozwalając na niewychodzenie z własnej strefy komfortu i nasilając postawy introwertyczne. Dodatkowo odcięcie dotychczasowych możliwości rozładowania napięć mogło spowodować zaostrzenie zachowań autoagresywnych i wzmóc poczucie bezradności ze względu na znaczne zmiany przyzwyczajeń i sposobu spędzania czasu przez osoby badane.

\section{Bibliografia}

[1] Ashton, M. C., Lee, K. (2007). Empirical, theoretical, and practical advantages of the HEXACO model of personality structure. Personality and Social Psychology Review, 11 (2), 150-166.

[2] Bagby, R. M., Costa Jr, P. T., Widiger, T. A., Ryder, A. G., Marshall, M. (2005). DSM-IV personality disorders and the Five-Factor Model of personality: A multi-method examination of domain - and facet-level predictions. European Journal of Personality, 19 (4), 307-324. DOI: 10.1002/per.563.

[3] Beck, A., Rush, A.J., Shaw, B.F., Emery, G. (1979). Cognitive therapy of depression. Nowy Jork: The Guilford Press

[4] Cierpiałkowska, L. (2017). Zaburzenie osobowości borderline. W: L. Cierpiałkowska, L., E. Soroko (red.), Zaburzenia osobowości. Problemy diagnozy klinicznej. (ss. 171-197). Poznań: Wydawnictwo Naukowe UAM.

[5] Costa, P., McCrae, R. (1992). Four ways Five Factors are basic. Personality and Individual Differences, 13 (6), 653-665.

[6] DeShong, H. L., Mullins-Sweatt, S. N., Miller, J. D., Widiger, T. A., Lynam, D. R. (2016). Development of a short form of the five-factor borderline inventory. Assessment, 23 (3), 342-352.

[7] Distel, M. A., Trull, T. J., Willemsen, G., Vink, J. M., Derom, C. A., Lynskey, M., Boomsma, D. I. (2009). The five-factor model of personality and borderline personality disorder: a genetic analysis of comorbidity. Biological Psychiatry, 66 (12), 1131-1138.

[8] Eysenck, H. J. (1992). Four ways Five Factors are not Basic. Personality and Individual Differences, 13 (6), 667-673.

[9] Grabski, B., Gierowski, J. (2012). Zaburzenia osobowości: różne spojrzenia i próby ich integracji. Psychiatria Polska, $46(5), 829-844$

[10] Jones, S. E., Miller, J. D., Lynam, D. R. (2011). Personality, antisocial behavior, and aggression: A meta-analytic review. Journal of Criminal Justice, 39 (4), 329-337.

[11] Kubacka-Jasiecka, D. (2006). Agresja i autodestrukcja z perspektywoy obronno-adaptacyjnych dażeń Ja. Kraków: Wydawnictwo Uniwersytetu Jagiellońskiego.

[12] Lee, K., Ashton, M. C. (b.d.). The HEXACO Personality Inventory - Revised. A measure of the six major dimensions of personality. Pobrane $\mathrm{z}$ : http://hexaco.org/scaledescriptions.

[13] Szarota, P., Ashton, M., Lee, K. (2007). Taxonomy and structure of the Polish personality lexicon. European Journal of Personality, 21, 823-852.

[14] Linowski, K., Wysocki, I. (2012). Agresja, autoagresja w przemoc w życiu człowieka. Przyczyny, przejawy, przeciwdziałanie i resocjalizacja. Radom: Politechnika Radomska.

[15] Łoś, Z. (2010). Rozwój psychiczny człowieka w ciagu całego życia. Wrocław: Wydawnictwo Uniwersytetu Wrocławskiego.

[16] Marcus, D. K., Zeigler-Hill, V. (2015). A big tent of dark personality traits. Social and Personality Psychology Compass, $9(8), 434-446$.

[17] Mosak, H. H. (1971). Lifestyle. W: A. G. Nikelly (red.), Techniques for behavior change (ss. 77-81).Springfield: Charles C. Thomas.

[18] Perlman, G., Gromatsky, M., Salis, K. L., Klein, D. N., Kotov, R. (2018). Personality correlates of self-injury in adolescent girls: disentangling the effects of lifetime psychopathology. Journal of Abnormal Child Psychology, 46 (8), 16771685.

[19] Pervin, L. A., John, O. P. (2002). Osobowoość - teoria i badania. Kraków: Wydawnictwo Uniwersytetu Jagiellońskiego.

[20] Pilecka, B. (2004). Kryzys psychologiczny. Wybrane zagadnienia. Kraków: Wydawnictwo Uniwersytetu Jagiellońskiego.

[21] Roszkowska, A. (2018). Agresja i autoagresja, oraz obraz siebie a relacje rodzinne wśród dorastającej młodzieży - analiza porównawcza. Zeszyty Naukowe Politechniki Ślaskiej. Organizacja i Zarzadzanie. 123. DOI:10.29119/16413466.2018.123.31

[22] Sharaf, A. Y., Thompson, E. A., Walsh, E. (2009). Protective effects of self-esteem and family support on suicide risk behaviours among at risk adolescents. Journal of Child and Adolescent Psychiatry Nursing, 22 (3), 160-168.

[23] Strus, W., Cieciuch, J., Rowiński, T. (2011). Kołowy model struktury cech osobowości w ujęciu Lewisa Goldberga. Studia Psychologica: Theoria et Praxis, 2 (11), 65-93.

[24] Strus, W., Cieciuch, J. (2014). Poza Wielką Piątkę - przegląd nowych modeli struktury osobowości. Polskie Forum Psychologiczne, 19 (1), 17-49. 
[25] Suchańska, A. (1998). Przejawy i uzwarunkowania psychologiczne pośredniej autodestruktywności. Poznań: Wydawnictwo Naukowe UAM.

[26] Trull, T. J., Widiger, T. A., Lynam, D. R., Costa, P. T., Jr. (2003). Borderline personality disorder from the perspective of general personality functioning. Journal of Abnormal Psychology, 112 (2), 193-202. https://doi.org/10.1037/0021843X.112.2.193

[27] Trull, T. J., Widiger, T. A., Lynam, D. R., Costa, P. T., Jr. (2005). Borderline personality disorder from the perspective of general personality functioning. Focus. 3 (3). 453-464

[28] Tsirigotis, K., Gruszczyński, W., Lewik-Tsirigotis, M., Kruszyna, M. (2011). Przejawy autodestruktywności pośredniej u osób po próbach samobójczych. Psychiatria i Psychologia Kliniczna, 11 (2), 83-91.

[29] van der Kolk, B. A., Perry, J. C. Herman, J. L. (1991). Childhood origins of self-destructive behavior. American Journal of Psychiatry, 148 (12), 1665-1671.

[30] Pużyński, S., Wciórka, J. (red.). (2000 lub 1998) Klasyfikacja zaburzeń psychicznych i zaburzeń zachowania w ICD10. Badawcze kryteria diagnostyczne. Kraków: Vesalius.

[31] Wojda, K. (2018). Środowisko rodzinne a podejmowanie zachowań autoagresywnych u osób z zaburzeniem osobowości typu borderline. Praca magisterska, Uniwersytet Jagielloński, obrona 17 października 2018 r. Promotor M. Wasilewska. Źródło: (https://ruj.uj.edu.pl/xmlui/handle/item/231938). 